\title{
Urinary Fluoride Excretion in Children Exposed to Fluoride Toothpaste and to Different Water Fluoride Levels in a Tropical Area of Brazil
}

\author{
Franklin Delano Soares FORTE ${ }^{1,2}$ \\ Suzely Adas Saliba MOIMAZ ${ }^{1}$ \\ Fábio Correia SAMPAIO \\ ${ }^{1}$ Department of Pediatric and Community Dentistry, Dental School of Araçatuba, \\ São Paulo State University, Araçatuba, SP, Brazil \\ ${ }^{2}$ Department of Community and Clinical Dentistry, Federal University of Paraíba, João Pessoa, PB, Brazil
}

\begin{abstract}
The aim of this study was to evaluate the urinary fluoride excretion of 2- to 7-year-old children exposed to different water fluoride concentrations in the city of Catolé do Rocha, PB, Brazil. Forty-two children were allocated to 3 groups according to the concentration of fluoride in the water: $\mathrm{G} 1$ ( $\mathrm{n}=10 ; 0.5-1.0 \mathrm{ppm}$ F), G2 ( $\mathrm{n}=17 ; 1.1-1.5 \mathrm{ppm} \mathrm{F})$ and $\mathrm{G} 3(\mathrm{n}=15 ;>1.51 \mathrm{ppm}$ F). The study was carried out in two 1-week phases with 1-month interval between the moments of data collection: in the first phase, the children used a fluoride toothpaste (FT) (1,510 ppm F) for 1 week, whereas in the second phase a non-fluoride toothpaste (NFT) was used. The urine was collected in a 24-h period in each week-phase according to Marthaler's protocol. The urinary fluoride excretion data expressed as mean (SD) in $\mu \mathrm{g} / 24 \mathrm{~h}$ were: G1-FT= 452.9 (290.2); G1-NFT= 435.1 (187.0); G2-FT= 451.4 (224.0); G2-NFT= 430.3 (352.5); G3FT=592.3 (390.5); and G3-NFT=623.6 (408.7). There was no statistically significant difference between the water fluoride groups, and regardless of the week phase (ANOVA, $\mathrm{p}>0.05$ ). The use of fluoride toothpaste $(1,510 \mathrm{ppmF})$ did not promote an increase in urinary fluoride excretion. There was a trend, though not significant, as to the increase of urine fluoride concentration in relation to fluoride concentrations in the water. The excretion values suggest that some children are under risk to develop dental fluorosis and information about the appropriate use of fluoride is necessary in this area.
\end{abstract}

Key Words: fluoride, urine, metabolism.

\section{INTRODUCTION}

There is strong evidence that the widespread use of fluoride has played an important role to the caries decline in developed countries (1). Brazilian toothpastes are fluoridated since 1989 and currently $97 \%$ of the toothpastes sold in Brazil are fluoridated. Water fluoridation and preventive programs at schools are also sources of fluoride exposure for Brazilian children. Therefore, monitoring fluoride intake in infants and preschool children is important, due to the risk for dental fluorosis. In addition, monitoring fluoride intake can provide data about the safety of the methods of caries prevention in relation to chronic fluoride exposure.

It is estimated that more than $90 \%$ of the children brush their teeth using toothpaste before the age of 2 . A significant number of children brush their teeth without adult supervision, and some children use more than 0.5 $\mathrm{g}$ of dentifrice in each brushing. Whitford (2) mentioned that children between 3 and 6 years old swallow approximately $25 \%$ of the dentifrice placed on the brush during dental hygiene.

Recent publications point out the role of fluoride toothpastes in the development of dental fluorosis (3-6). The premature use of fluoride toothpastes $(1,500 \mathrm{ppmF})$ and involuntary ingestion has been identified as a risk factor for dental fluorosis in Paraiba. This risk is increased in regions with natural water fluoride concentrations where the fluoride intake can reach $0.18 \mathrm{mg} / \mathrm{kg} /$ day which is twice above the threshold value for dental

Correspondence: Prof. Dr. Franklin Delano Soares Forte, Rua Travessa Antônio L. Batista, 71, apto. 402, Bancários, 58051-110 João Pessoa, PB, Brasil. Tel: +55-83-235-5160. e-mail: fdsforte@terra.com.br

Braz Dent J 19(3) 2008 
fluorosis (7).

Approximately $50 \%$ of the ingested fluoride is excreted via urine within the $24 \mathrm{~h}$ following the intake, and the major part is kept associated to calcified tissues $(2,8)$. Therefore, fluoride excretion may be a good indicator of fluoride intake in children and adults, especially in first-infancy children, who are susceptible to develop dental fluorosis (9-11).

Based on such information, the aims of this study were to verify the pattern of urinary fluoride excretion of 2- to 7-year-old children exposed to different water fluoride concentrations in the drinking water in a tropical semi-arid area of Brazil, as well as to assess the influence of fluoride toothpastes on fluoride excretion.

\section{MATERIAL AND METHODS}

The study was carried out after approval by the local Research Ethics Committee of the Federal University of Paraíba, Brazil. Only children whose parents signed a written informed consent were considered as eligible.

Selection of the region to be evaluated (rural zone of the city of Catolé do Rocha, PB, Brazil) was based on information about the existence of natural fluoride in the water (7). The fluoride levels were measured as ranging from 0.5 and $3.26 \mathrm{ppmF}$. Water samples were collected during the study development.

Forty-two children (25 males and 17 females), were enrolled. The research subjects were allocated in 3 groups according to the fluoride concentration in the water: $\mathrm{G} 1(\mathrm{n}=10)$ with $0.5-1.0 \mathrm{ppmF}$; $\mathrm{G} 2(\mathrm{n}=17)$, with 1.1-1.5 ppmF; and G3 $(n=15)$ with fluoride above 1.51 ppmF (maximum of $3.26 \mathrm{ppmF}$ ). Urine samples were collect in 1,500-mL recipients in two occasions, based on Marthaler's et al. (11) protocol. The first urine sample collection was carried out after the child had used fluoride toothpaste (FT) with 1,510 ppmF (Sorriso ${ }^{\circledR}$; Colgate-Palmolive, São Paulo, SP, Brazil) for 1 week. After 1 month, the children used a non-fluoride toothpaste (NFT) (Phillips ${ }^{\circledR}$ Glaxo Smithkline, São Paulo, SP, Brazil) during 1 week, and then the second urine sample was collected. The parents were instructed to clean their children's teeth with the respective toothpaste, toothbrush and dental floss. Children who did not seem to have control over nocturnal excretions, those who were out of the age group, and those who did not make up the 24-h period for the collection or excreted smaller volumes $(<180 \mathrm{~mL})$ were withdrawn from the trial.
During the second collection, 8 children were withdrawn from the study due to either a small urine volume excreted or who refused to take part. Anthropometric measurements (height and weight) were collected and used for evaluation of the individual nutritional level.

Aliquots of $15 \mathrm{~mL}$ of urine and water were frozen and sent for analysis at the Oral Biology Laboratory of the Federal University of Paraíba, Brazil. Prior to analysis, standards were prepared by serial dilution of 100 ppm NaF stock solution (Orion Research, Cambridge, MA, USA). The standard curve had a correction coefficient $\geq 0.99$. Fluoride analyses in the urine and water were determined using an ion-specific electrode (96-09 BN; Beverly, MA, USA) and a 720 A meter (Orion Research), after adding an equal volume of TISAB II.

The total volume of water ingested by the child was also measured. Parents were asked to keep the drinking water in 2-mL recipients during the course of the study. After measurement with a measuring cylinder, the results were recorded individually, as described by Marthaler et al. (11).

The data was analyzed statistically using the SPSS v. 10.0 statistical software package (SPSS Inc., Chicago, IL, USA). The results were presented based on descriptive methods (means and standard deviation) and Mann Whitney U-test non-parametric test. ANOVA and Pearson's correlation were applied when appropriate. Differences were considered significant when $\mathrm{p}<0.05$.

\section{RESULTS}

Table 1 shows the general data about the pattern of oral hygiene and toothpaste usage among the children enrolled in the study. Regarding the volume of urine in the 2 collection phases (FT and NFT), a positive correlation was observed (Pearson's correlation coefficient $r=0.48$ and $p<0.05$ ). Only 3 children were identified as under-nourished but there was a wide range of weight (9.5 up to $21.5 \mathrm{~kg}$ ).

Table 2 presents the urinary fluoride excretion data under different unit of measurements $(\mu \mathrm{g} / \mathrm{kg} 24 \mathrm{~h}$; $\mu \mathrm{g} / 24 \mathrm{~h} ; \mu \mathrm{g} / \mathrm{h})$. It can be observed a trend to an increase of fluoride excretion according to the fluoride concentrations in the drinking water. However, there was no statistically significant difference among the groups (ANOVA, $\mathrm{p}>0.05$ ).

Table 3 presents the Pearson's correlation coefficient of several variables of the study. Regarding the 
Table 1. Description of toothpaste use and nutritional status.

\begin{tabular}{lc}
\hline \multicolumn{1}{l}{ Variable } & $\mathrm{n}(\%)$ \\
\hline Toothpaste amount & \\
$\quad$ Do not use & $5(11.9)$ \\
$\quad$ Small amounts & $7(16.6)$ \\
Up to half the length of bristles & $16(38.0)$ \\
$\quad$ Whole extension of the bristles & $14(33.3)$ \\
Toothpaste F Concentration & \\
$\quad$ Do not use & $5(11.9)$ \\
For children (600 ppm) & $5(11.9)$ \\
Conventional (1500 ppm) & $32(76.2)$ \\
Oral Hygiene & \\
Do not carry out & \\
Sometimes & $5(11.9)$ \\
Always & $11(26.2)$ \\
Z score & $26(61.9)$ \\
$\quad$ Well-nourished & \\
Under-nourished & $39(92.8)$ \\
\end{tabular}

individual 24-h values of urine excretion, the highest values were between 1,500 and $1,600 \mu \mathrm{g} / 24 \mathrm{~h}$.

\section{DISCUSSION}

Several studies have monitored urine excretion during fluoridation programs of salt $(11,12)$, milk $(13,14)$ and water $(9,15)$, but few have included the additional influence of fluoride toothpaste $(15,16)$.

Most studies collected the urine in different periods, and a small number of studies collected urine within $24 \mathrm{~h}$. The present study was based on Marthaler's et al. (11) protocol in which urine is collected in $24 \mathrm{~h}$. This is regarded as a reliable period of time for urine collection. The areas under study, rural communities in the Semi-Arid region of Paraíba, Brazil, are regarded to have stable concentrations of natural fluoride in the drinking water (7). Therefore, any variation in fluoride urine excretion can be mainly attributed to individual

Table 2. Urinary fluoride excretion $(\mu \mathrm{g} / \mathrm{kg} 24 \mathrm{~h} ; \mu \mathrm{g} / 24 \mathrm{~h} ; \mu \mathrm{g} / \mathrm{h})$ means $(\mathrm{SD})$ in relation to fluoride concentration in the drinking water in two occasions: using fluoride toothpaste (FT) and non-fluoride toothpaste (NFT).

\begin{tabular}{lccccccc}
\hline $\begin{array}{c}\text { water } \\
(\mathrm{ppmF})\end{array}$ & $\mathrm{n}$ & $\begin{array}{c}\mathrm{FT} \\
(\mu \mathrm{g} / \mathrm{kg} 24 \mathrm{~h})\end{array}$ & $\begin{array}{c}\mathrm{NFT} \\
(\mu \mathrm{g} / \mathrm{kg} 24 \mathrm{~h})\end{array}$ & $\begin{array}{c}\mathrm{FT} \\
(\mu \mathrm{g} / 24 \mathrm{~h})\end{array}$ & $\begin{array}{c}\text { NFT } \\
(\mu \mathrm{g} / 24 \mathrm{~h})\end{array}$ & $\begin{array}{c}\mathrm{FT} \\
(\mu \mathrm{g} / \mathrm{h})\end{array}$ & $\begin{array}{c}\text { NFT } \\
(\mu \mathrm{g} / \mathrm{h})\end{array}$ \\
\hline $0.5-1.0$ & 10 & $24.9(12.0)$ & $26.3(09.8)$ & $452.9(290.0)$ & $453.1(187.0)$ & $18.8(12.0)$ & $18.1(07.7)$ \\
$1.1-1.5$ & 17 & $26.3(12.8)$ & $27.6(24.6)$ & $451.4(224.0)$ & $430.3(352.5)$ & $18.7(09.3)$ & $17.9(14.6)$ \\
$>1.51$ & 15 & $30.7(17.2)$ & $32.2(21.1)$ & $592.3(390.5)$ & $623.6(408.7)$ & $25.1(15.7)$ & $25.9(17.0)$ \\
Total & 42 & $27.5(14.2)$ & $29.0(20.3)$ & $501.6(307.8)$ & $505.3(349.6)$ & $21.0(12.6)$ & $21.0(14.5)$ \\
\hline
\end{tabular}

Table 3. Pearson's correlation coefficients (r) between the studied variables.

\begin{tabular}{|c|c|c|c|c|c|c|c|c|c|c|}
\hline & $\begin{array}{l}\text { Weight } \\
(\mathrm{kg})\end{array}$ & $\begin{array}{l}\text { Height } \\
(\mathrm{cm})\end{array}$ & $\begin{array}{c}\text { Ingested } \\
\text { water } \\
(\mathrm{mL})\end{array}$ & $\begin{array}{c}\text { Urine } \\
\text { volume } \\
\text { FT }(\mathrm{mL})\end{array}$ & $\begin{array}{c}\text { Urine } \\
\text { volume } \\
\text { NFT }(\mathrm{mL})\end{array}$ & $\begin{array}{c}\mu \mathrm{g} / \mathrm{h} \\
\mathrm{FT}\end{array}$ & $\begin{array}{l}\mu \mathrm{g} / \mathrm{h} \\
\mathrm{NFT}\end{array}$ & $\begin{array}{c}\mu \mathrm{g} / 24 \mathrm{~h} \\
\mathrm{FT}\end{array}$ & $\begin{array}{c}\mu \mathrm{g} / 24 \mathrm{~h} \\
\mathrm{NFT}\end{array}$ & $\begin{array}{c}\mu \mathrm{g} / \mathrm{kg} / 24 \mathrm{~h} \\
\mathrm{FT}\end{array}$ \\
\hline Weight (kg) & - & - & - & - & - & - & - & - & - & - \\
\hline Height $(\mathrm{cm})$ & $0.76^{* *}$ & - & - & - & - & - & - & - & - & - \\
\hline Ingested water (mL) & 0.24 & 0.24 & - & - & - & - & - & - & - & - \\
\hline Urine volume $(\mathrm{mL}) \mathrm{FT}$ & $0.40 * *$ & $0.34 *$ & 0.28 & - & - & - & - & - & - & - \\
\hline Urine volume (mL)NFT & 0.29 & $0.38^{*}$ & 0.25 & $0.48 * *$ & - & - & - & - & - & - \\
\hline$\mu \mathrm{g} / \mathrm{h} \mathrm{FT}$ & $0.54 * *$ & $0.42 * *$ & $0.41 * *$ & $0.76 * *$ & - & - & - & - & - & - \\
\hline$\mu \mathrm{g} / \mathrm{h}$ NFT & $0.42 *$ & $0.39 *$ & $0.35^{*}$ & - & $0.45^{* *}$ & $0.55 * *$ & - & - & - & - \\
\hline$\mu \mathrm{g} / 24 \mathrm{~h} \mathrm{FT}$ & $053 * *$ & $0.40 * *$ & $0.46^{* *}$ & $0.75^{* *}$ & - & 0.99 & - & - & - & - \\
\hline$\mu \mathrm{g} / 24 \mathrm{~h}$ NFT & $0.42 *$ & $0.39 *$ & $0.35^{*}$ & - & $0.95 * *$ & - & $1,0 * *$ & $0.5^{* *}$ & - & - \\
\hline$\mu \mathrm{g} / \mathrm{kg} / 24 \mathrm{~h} \mathrm{FT}$ & 0.12 & 0.09 & $0.37^{*}$ & $0.62 * *$ & - & $0.86^{* *}$ & - & $0.8^{* *}$ & - & - \\
\hline$\mu \mathrm{g} / \mathrm{kg} / 24 \mathrm{~h}$ NFT & 0.12 & 0.13 & 0.23 & - & $0.34 * *$ & - & $0.91 * *$ & - & $0.91 * *$ & $0.42 *$ \\
\hline
\end{tabular}

$*=\mathrm{p}<0.01 . * *=\mathrm{p}<0.05 . \mathrm{FT}=$ Fluoride toothpaste NFT $=$ Non-fluoride toothpaste. 
variation in fluoride intake or bioavailability of fluoride for the assessed age group. The mean volumes of $24 \mathrm{~h}$ urine collection were $354.6 \mathrm{~mL}$ and $360.7 \mathrm{~mL}$ (for the first and second collection respectively) suggesting that the collection was complete. These values are close to those observed by Villa et al. (17), but lower than those observed by other studies that found $500-600 \mathrm{~mL}$ $(10,13,15,18)$. According to Ketley and Lenon (14), low volume of urine excretion is one of the explanations for small samples in various urine clinical and epidemiological trials. Therefore, the exclusion of 8 subjects during the period of low fluoride exposure from toothpaste (NFT) in the present study is not relevant since the interest is in high values of fluoride excretion and the urine volume in both collections were fairly correlated.

The majority of the participants $(71 \%)$ stated the use of fluoride toothpaste on the whole bristle length $(n=14)$ or up to half the bristle length $(n=16)$; and the most commonly used toothpaste brand had $1,510 \mathrm{ppmF}$ (Table 1). These data support the information about the inappropriate use of high fluoride concentration toothpaste among children in Paraiba (7). However, the use of fluoride toothpaste (FT) for 1 week did not increase the urinary fluoride excretion significantly (Table 2). Pessan et al. (5) did not observe difference between fluoride excretion from fluoridated dentifrices and placebo. Although a slight increase was observed when using together with fluoridated varnish, but after $24 \mathrm{~h}$, the excretion value was close to baseline.

Ekstrand (19) observed that individuals who have been exposed to a high concentration of fluoride from drinking water, then move to a region with low concentration of fluoride in water public systems, remain with a high fluoride concentration in urinary excretion for a long time. This probably happens due to the continuous bone tissue remodeling. Different rate of turnover of fluoride in the individual's bone structure have an important role in fluoride excretion, due to the bone tissue development stage $(2,14,17)$. The present data support this point of view since the anthropometric measurements (weight and height) were correlated to urinary fluoride excretion, in $\mu \mathrm{gF} / \mathrm{h}$ and $\mu \mathrm{gF} / 24 \mathrm{~h}$, in both collections.

In addition to the influence of bone tissue's metabolic activity during growth and development (8), one must consider that individual variation in short periods are also common. This was noted by Marthaler et al. (10) in four nocturnal collections from Swiss children. Ketley and Lenon (14) verified the individual excretion variation between 0.25 and $0.39 \mathrm{mg} /$ day. High values of SD (standard deviation) in urinary fluoride excretion rates are not rare and therefore it is necessary to present in different ways (Table 2) (9).

Means of 502.1 and $505.3 \mu \mathrm{g} / 24 \mathrm{~h}$ (for FT and NFT, respectively) were observed (Table 2). These values are close to those found by Rugg-Gunn et al. (9) (420 and $550 \mu \mathrm{gF} / 24 \mathrm{~h}$ ), whose subjects were exposed to 0.8-1.1 ppmF fluoridated water systems in Sri Lanka and England, respectively. The values were also close to those found by Haftenberger et al. (18) (476 $\mu \mathrm{gF} / 24 \mathrm{~h}$ ), with German children who used fluoridated salt and toothpaste. However, the mean values of the present study were lower than those found by Baez et al. (20), where fluoride concentration in the water is $1.32 \mathrm{ppmF}$. In Baez's et al. study (20), it is stated that mean excretion values between 400 and $500 \mu \mathrm{gF} / 24 \mathrm{~h}$ in 3 to 6 year old children could be considered an "optimum" indicator for fluoride ingestion. Higher values could be an indication of public health concern. The data from Paraiba showed that children exposed to fluoride concentration in the drinking water above $1.51 \mathrm{ppmF}$, presented excretion values above the values recommended as "optimal" by Baez et al. (20) (592.3 and $623.6 \mu \mathrm{gF} / 24 \mathrm{~h}$, for FT and NFT collections, respectively). Even in "optimal" water fluoride concentration areas (G2 and G1) fluoride excretion above $400 \mu \mathrm{gF} / 24 \mathrm{~h}$ were observed (Table 2 ), suggesting that a risk for dental fluorosis is taking place.

The need for liquid ingestion is dependent on cultural and climatic factors. Mean fluoride excretion seems to be higher in Sri Lanka than in England, even though both places have water fluoridation around 1 ppmF. In addition to different fluoride sources, a possible explanation is due to the fact that children in Sri Lanka ingest more water than children in England due to the hot climate (9). The studied area in the Brazilian State of Paraiba has a hot and dry climate around 27 to $35^{\circ} \mathrm{C}$, thus demanding a high liquid ingestion, especially water. This study observed that the mean liquid ingestion was $800 \mathrm{~mL}$, but could reach $1,300 \mathrm{~mL}$ in some cases. The high amount of ingested water was correlated to fluoride excretion in $\mu \mathrm{g} / \mathrm{h}$ (in both collections); in $\mu \mathrm{g} / 24 \mathrm{~h}$ (both collections); and in $\mu \mathrm{g} / \mathrm{kg} / 24 \mathrm{~h}$ (FT collection) and thus is an important source of fluoride (Table 3 ). The wide range of weight of the children might explain the wide 
range of the fluoride excretion values when presented in $\mu \mathrm{g} / \mathrm{kg} / 24 \mathrm{~h}$.

In conclusion, the use of fluoride toothpaste (1,510 ppmF) for a period of 1 week did not promote an increase in urinary fluoride excretion patterns. There was, however, a trend, though not significant, to the increase of urine fluoride concentration with the increase of fluoride concentrations in the water. A correlation was observed between the amount of water ingested by the children and the fluoride excretion pattern in $\mu \mathrm{gF} /$ $\mathrm{h}, \mu \mathrm{gF} / 24 \mathrm{~h}$ and $\mu \mathrm{gF} / 24 \mathrm{~h}$. The excretion values suggest that some children are under risk to develop dental fluorosis and information about the appropriate use of fluoride is necessary in this area.

\section{RESUMO}

O objetivo desse estudo foi verificar o padrão de excreção urinária de fluoretos em crianças de 2 a 7 anos, de ambos os gêneros, moradoras do Sertão da Paraíba, divididas em três grupos conforme concentração de fluoretos nas águas: G1 (0,51,0 ppmF); G2 (1,1-1,5 ppmF) e G3 (>1,51 ppmF). O estudo foi desenvolvido em duas etapas: a primeira $(n=42)$ com a utilização de dentifrício fluoretado (1510 ppmF) (DF) durante uma semana e a segunda $(n=34)$ com dentifrício sem fluoretos (DSF), com intervalo de um mês entre as coletas. A urina foi coletada em 24 horas seguindo a metodologia de Marthaler. Não foi observada diferença significante entre os grupos estudados e excreção urinária de fluoretos em ambas etapas. A excreção urinária de fluoretos em $\mu \mathrm{g} / 24 \mathrm{~h}$ (média e desvio padrão) foram: $\mathrm{G} 1-\mathrm{DF}=452,9(290,2) ; \mathrm{G} 1-\mathrm{DSF}=435,1(187,0) ; \mathrm{G} 2-\mathrm{DF}=451,4$ $(224,0)$; G2-DSF= 430,3 (352,5); G3-DF= 592,3 (390,5); G3$\mathrm{DSF}=623,6(408,7)$. Observou-se uma tendência, embora não significativa, quanto ao aumento nas concentrações de fluoretos na urina em relação as concentrações na água de consumo. Os valores de excreção sugerem que algumas crianças estão sob o risco de desenvolver fluorose dentária e orientação sobre o uso apropriado de flúor é necessária nesta área.

\section{REFERENCES}

1. Bratthall D, Hansel PG, Sundberg HH. Reasons for caries decline: what do the experts believe? Eur J Oral Sci 1996;104:416-422.

2. Whitford G. The metabolism and toxicity of fluoride. New York: Karger, 1996.

3. Oliveira MJL, Paiva SM, Martins LHPM, Ramos-Jorge ML, Lima YBO, Cury JA. Fluoride intake by children at risk for the development of dental fluorosis: comparison of regular dentifrices and flavored dentifrices for children. Caries Res 2007;41:460-466.
4. Paiva SM, Lima YBO, Cury JA. Fluoride intake by Brazilian children from two communities with fluoridated water. Community Dent Oral Epidemiol 2003;31:184-191.

5. Pessan JP, Pin MLG, Martinhon CCR, Silva SMB, Buzalaf MAR. Analysis of fingernails and urine as biomarkers of fluoride exposure from dentifrice and varnish in 4-to 7-yearold children. Caries Res 2005;39:363-370.

6. Cury JA, Tenuta LM, Ribeiro CC, Paes Leme AF. The importance of fluoride dentifrices to the current dental caries prevalence in Brazil. Braz Dent J 2004;15:167-174.

7. Carvalho TS, Kehrle H, Sampaio FC. Prevalence and severity of dental fluorosis among students from João Pessoa, PB, Brazil. Bras Oral Res 2007;21:198-203.

8. Whitford G. The physiological and toxicological characteristics of fluoride. J Dent Res 1990;69:539-549.

9. Rugg-Gunn AJ, Nunn JH, Ekanayake L, Saparamadu KDG, Wright WG. Urinary fluoride excretion in 4 year old children in Sri Lanka and England. Caries Res 1993;27:478-483.

10. Marthaler TM, Binder-Fuchs M, Baez RJ, Menghini G. Urinary fluoride excretion aged 3 and 4 consuming fluoridated domestic salt. Acta Med Dent Hel 2000;5:89-97.

11. Marthaler TM. Monitoring of renal fluoride excretion in community preventive programmers on oral health. World Health Organization. Geneva; 1999.

12. Obry-Musset AM, Bettembourg D, Cahen PM, Voegel RC, Frank RM. Urinary fluoride excretion in children using potassium fluoride containing salt or sodium fluoride supplements. Caries Res 1992;26:367-370.

13. Ketley CE, Lenon MA. Determination of fluoride intake from urinary fluoride excretion data in children drinking fluoridated school milk. Caries Res 2001;35:252-257.

14. Ketley CE, Lenon MA. Urinary fluoride excretion in children drinking fluoridated school milk. Int $\mathrm{J}$ Paediatr Dent 2000;10:260-270.

15. Udipi SA, Subbulakshmi G, Chandrakala P, Limaye M, Vaidya A. Influence of fluoride containing toothpaste on serum and urine fluoride levels in children. J Pierre Fauchard Acad 1993;7:121-143.

16. Ketley CE, Cochran JA, Holbrook P, Sanches L, Van Loveren C, Oila AM et al.. Urinary fluoride excretion by preschool children in six European countries. Community Dent Oral Epidemiol 2004;32(suppl. 1):62-68.

17. Villa A, Anabalón M, Cabezas L. The fractional urinary fluoride excretion in young children under stable fluoride intake conditions. Community Dent Oral Epidemiol 2000;28:344-355.

18. Haftenberger M, Viergutz G, Neumeister V, Hetzer G. Total fluoride intake and urinary excretion in German children aged 3-6 years. Caries Res 2001;35:451-457.

19. Ekstrand J. Fluoride metabolism. In: Fejerskov O, Ekstrand J, Burt B. (Editors). Fluoride in Dentistry. 2nd ed. Copenhagen: Munksgaard, 1996. p. 55-68.

20. Baez RJ, Baez MMX, Marthaler TM. Urinary fluoride excretion by children 4-6 years old in south Texas community. Pam Am J Public Health 2000;7:242-247.

Accepted March 14, 2008 